\section{South African Higher Education: The Challenge of Change}

\section{Saleem Badat}

Saleem Badat is director of the Education Policy Unit, University of Western Cape. Address: Private Bag x 17, Bellville 7530, South Africa. Fax: 021-9593278. E-mail: <sbadat@epu.uwc.ac.za>.

A $\mathrm{s}$ is characteristic of periods of political and social transition, South African higher education is in considerable flux. Multiple initiatives are under way as the new democratic government, the new advisory Council on Higher Education, various stakeholder organizations, and the 21 universities and 15 technikons themselves attempt to reconstruct and transform apartheid's higher education legacy in relation to new policy goals, formulated through a long and extensive process of research, debate, and consultation.

The higher education transformation agenda has its source in three related conditions. First, the inherited system was designed, in the main, to reproduce, through teaching and research, white privilege and black subordination in all spheres of society. Higher education was characterized by a lack of vision and a paralysis in policymaking, and problems of legitimacy and other conflicts around governance. Further, it was fragmented and divided along racial and ethnic lines, and reflected severe social inequalities of "race" and gender with respect to student access and success and the composition of academic staff. Finally, major institutional inequities existed between what are termed historically white institutions (HWIs) and historically black institutions (HBIs). Thus, a key policy imperative is to transform higher education so that it becomes more socially equitable internally and promotes social equity more generally.

Second, whereas previously research and teaching were shaped by the socioeconomic and political priorities of the apartheid separate development program, higher education is now called on to address and respond to the development needs of a democratic South Africa. These needs are crystallized in the Reconstruction and Development Programme of 1994 as a fourfold commitment: "meeting basic needs of people," "developing our human resources," "building the economy," and "democratizing the state and society."

Finally, South Africa's transition is occurring during a period that has witnessed the emergence of a global economy and changes in the world captured by the concept "globalization." It is recognized that, in the words of Martin Carnoy, economic growth, is "increasingly dependent on knowledge and information applied to production, and this knowledge is increasingly science-based." Moreover, there is broad acceptance for Manuel Castells' argu- ment that "if knowledge is the electricity of the new informational international economy, then institutions of higher education are the power sources on which a new development process must rely." ${ }^{2}$ Thus, a related challenge facing higher education is to produce through research and teaching-learning programs the knowledge and human resources that will enable South Africa to engage with and participate in a highly competitive global economy.

Higher education policy development, from the $\mathrm{Na}-$ tional Commission on Higher Education of 1995, to the Higher Education Act of 1997, and the white paper on higher education entitled, "A Programme for Transformation of Higher Education in South Africa," has taken as its point of departure this triple challenge-overcoming the apartheid legacy, contributing to reconstruction and development, and positioning South Africa to effectively engage globalization. The following policy initiatives have been drawn up from identified higher education priorities:

- development of a single, differentiated, and coordinated system;

- cooperative governance of the system, institutions, and partnerships;

- increased and broadened participation within higher education to meet human resource needs and advance social equity;

- curriculum restructuring and knowledge production that are responsive to societal interests and needs;

- quality assurance through assessment and promotion of quality and accreditation of programs;

- incorporation of higher education programs and qualifications within a national qualifications framework designed to promote articulation, mobility, and transferability; - improved institutional planning and management and the development of three-year institutional plans; and

- state funding on the basis of allocated student enrollments and accredited programs with redress funding to overcome historical institutional inequities

\section{The higher education transformation agenda has its source in three related conditions.}

Despite a high level of consensus around policy goals, there continues to be contestation regarding instruments, mechanisms, and procedures for achieving policy goals. Moreover, implementation of policy is constrained by a number of factors.

- A new funding framework oriented toward the new policy goals is yet to be put into place. Declining state subsidies, limited funds for student aid, and high levels of stu- 
dent debt mean that institutions are experiencing severe financial pressures at the same time as they are being required to restructure and transform. Already, retrenchments of academic and administrative staff have occurred at a number of institutions, and the exclusion of students on financial grounds is becoming an area of perennial conflict. This, together with the intensification of academic workload has had a adverse effect on staff morale.

- The overall shape and size of the higher education system remains a thorny problem, along with the question of whether South Africa can afford 36 institutions. An important issue is how to balance the differing needs of the drive toward global competitiveness and the goal of redistributive reconstruction and development. Another challenge is to work out what this all means for individual institutions or for groupings of institutions - the HWIs and HBIs—and for universities and technikons. Should all higher education institutions be oriented toward both needs or should there be a functional differentiation. Is this likely to result in one set of institutions, the HWIs, becoming oriented toward the global pole and another set, the HBIs, becoming reconfigured to serve the redistributive reconstruction and development pole? Will these choices be left to the institutions themselves or will the state play an active role?

- Instead of increased participation in higher education, some institutions are experiencing declining student applications and enrollments, especially in the social sciences and humanities. Related to this, public institutions are having to cope with increasing and strong competition from private international and local providers of higher education.

- There is little unanimity as to what constitutes "programs" and whether programs need to be interdisciplinary or can also be discipline based. In this regard, there is, of course, the fear that a purely interdisciplinary concept of programs could have adverse consequences for the disciplines.

- Higher education institutions are concerned about registering qualifications based on "unit standards" (modules), under the National Qualifications Framework, as opposed to whole qualifications. The fear is that a unit standards system "atomizes" learning into the smallest units, but does not lend itself to assessment of the overall outcome. By contrast, a system based on whole qualifications evaluates coherent and integrated qualifications through assessable outcomes.

- The new system of cooperative governance entails a re-definition of the relationship between and responsibilities of key governmental and nongovernmental higher education bodies. This is yet to be accomplished in practice. Moreover, higher education policy and planning expertise is in short supply, with the result that all these bodies experience capacity problems in the face of further policy development and implementation.

Many of the challenges noted are, of course, not unique to South African higher education. This period of political and social transition places special pressures on higher education-and provides special opportunities as well.

\section{Notes}

1. Martin Carnoy, "Higher Education in a Global Innovation Economy" (paper presented at a Joint Centre for Higher Education Transformation and Human Sciences Research Council Seminar on Globalisation, Higher Education, High-Level Training, and National Development, 31 July 1998, Pretoria).

2. Manuel Castells, "The University System: Engine of Development in the New World Economy," in Improving Higher Education in Developing countries, ed. A. Ransom, S-M. Khoo, and V. Selveratnam (Washington, D.C.: World Bank, 1993).

\section{Vietnamese Higher Education: In Search of an Identity}

\section{Hoa Tran}

Hoa Tran is a consultant to UNICEF and other agencies. Address: 11 rue du Belevedere, 56400 Auray, France.

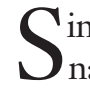
nce the adoption of Doi moi (renovation) in 1986, Viet namese higher education has moved away from its former Soviet model. Characterizing the country's system of higher education today, however, is not as straightforward a task as one might assume. Some changes suggest that Vietnam is taking on certain aspects of university patterns in the United States, the United Kingdom, Australia, and some parts of Southeast Asia. At the same time, the Vietnamese leadership maintains that Vietnam is still pursuing Marxism-Leninism, and universities are still called upon to instill this philosophy in their students. The contradiction within the education sys-

tem between the official line and reality is creating an "identity crisis" in Vietnam's higher education system.

Plus ça change...

In its first major change, the government policy responded to the substantial unmet demand for access by allowing universities to accept fee-paying students. Higher education is no longer a responsibility of the state alone; the majority of individuals are expected to pay their share. A university now enrolls both regular students, who receive full or partial scholarships, and nonregular students, who are fee-paying. With the dramatic expansion of higher education during the last several years, and given the significant revenues accruing to universities from nonregular students, their number has overtaken that of regular students. In 1997, out of a total of over 500,000 students, the nonregular/regular ratio was 51:49_ and the trend continues.

Against the background of the global expansion of private higher education, changes in Vietnamese higher edu- 